\title{
A EUROPEAN PERSPECTIVE ON THE REVOLUTIONARY SCHOOL OF MANAGEMENT
}

\author{
Andrew Adcroft, Robert Willis and Colin Clarke-Hill
}

(Forthcoming: European Business Review, May 2004, Issue 3)

\begin{abstract}
"To give a name to a thing is gratifying ... but it is also dangerous: The danger consists in one's becoming convinced that all is taken care of and that once named the phenomenon has also been explained" Primo Levi

"The concept has increasingly been overworked, debased and almost done to death. By a process of the inflation of vocabulary what formerly might be termed a 'shift' or a 'change' becomes a 'revolution' to win a place in the sun for his own specialized wedge of research" Porter and Teich
\end{abstract}

The volume of research output on management revolutions is growing at an alarming rate. For example, since 1997, the Library of Congress has amassed over 4,500 new books, journals and articles on this theme that cover subjects as diverse as information technology, organizational change, organizational culture, quality, customer service, human resource management, marketing, operations, logistics, the environment, organizational learning and innovation. More recently, there has been a significant growth in the volume of literature on revolutions in both the theory and practice of strategic management. What becomes clear, from even the most cursory examination of this management literature on change and transformation, is the perceived need for organizations to in some way or other reinvent themselves; the modern turbulence created by technology, globalisation and all the rest requires new forms of organizational behaviour and management. The net result of all this is that change has become the most important item on the agenda of modern management. Where previous management gurus talked about Japanisation and incremental change (Womack, Jones and Roos 1990) or excellence and continuous change (Peters and Waterman, 1982) now the gurus talk about transformation and revolution (Hamel, 2000) and what follows these changes in prescription is a concomitant dramatisaton and sensationalisation of the language used.

This exponential rise in the use of revolutionary language may prove Levi's point that, if we want to really understand a phenomenon, we need to do more than just give it a name and should avoid the use of glib catch phrases and clichés. Central to the debate on the manager as revolutionary is the complex issue of what drives it and the motivations and outcomes behind it. Is it, on the one hand, organizational necessity brought about by the revolutionary changes that are taking place in the modern world or is it, for those who are more skeptical of these kind of changes, a result of little more than management hubris? J. K. Galbraith argued that, for many economists "it is a far, far better thing to have a firm anchor in nonsense than to put out on the troubled sea of thought" and, as Meier (1996) has argued, this new school of management may reflect much the same thing; it could be little more than an attempt to reaffirm the centrality of management in organizational discourse at a time when the power to act coexists, paradoxically, with a powerlessness to change anything. 
The revolutionary school assumes that descriptive models can have prescriptive power and, rather than unravelling the Gordian Knot, there is an increasing focus on cutting through it via the adoption of off-the-peg solutions that can somehow transform a stable organisation into a revolutionary organisation. Like Fromm (1960) we would argue for the inadequacy of "reciting optimistic formulae" and it may also be a useful illustration of Porter and Teich's point about the purpose of management research being the promotion of output rather than ideas. This notion is reinforced by Chaharbaghi and Willis (1998) who argue that a great deal of management research is part of a "model making industry" which has "no real purpose".

The aim of this article is to dissect some of the key elements of this revolutionary school of management by analyzing it from a European perspective. The article is organized in a fairly straightforward way. It will first consider the political origins of revolutions before examining some of the key themes and texts that draw on these origins. It will then consider two case studies of European revolutions in action: The revolution in the European business environment over the past decade and a half and more recent attempts at transformation in Ford's European operations. The article will conclude by considering some of the implications of this trend. A central theme that runs through the article is that talk of revolutions in management often misses a number of key points about both the political origins of the term and the activity that it describes. The article will argue that the revolutionary school may offer a misleading description of the current age and, therefore, an inappropriate prescription for strategies to meet the challenges of the current age.

\section{Lost in the Translation: The political origins of the management revolution}

"The revolution cannot draw its power from the past, but only from the future. It cannot begin with itself before it has stripped itself of all superstitions concerning the past" Karl Marx

"A set of principles laid down more than two centuries ago has shaped the structure, management and performance of businesses throughout the nineteenth and twentieth centuries. We say that the time has come to retire those principles and to adopt a new set" Hammer and Champy

Hegel argued that success of any type, including successful revolutions, requires a good theory. In this section of the article we will consider the theoretical origins of the revolutionary school of management and the concept of revolution. In particular we will compare and contrast some of the key elements and themes of the political and management schools. The section will show that, in respect to language and terminology, there are some similarities between the two schools and the main source of this similarity is in the expressions of radical change. However, the section will also argue that the management school has done little more than replicate the language of revolution and has paid scant regard to the activity or process of revolutions: In making the shift from politics to management there has been a substantial dilution of the intellectual rigour which underpins the political concept of revolution.

An interesting, and relevant, diversion from the political concept of revolution is a consideration of the engineering concept of revolution that may, in any case, predate 
the political term. In engineering the concept can be defined as a single and complete orbit. This definition has relevance if we consider one of the earliest usages of the term in a political sphere that came in 1688 with the Glorious Revolution and the accession to the throne of William of Orange. This first example of political revolution was a response, not to the inequities or irrelevance of the status quo, but rather to change bought about by James II's increasing toleration of the Roman Catholic church: In its first usage, therefore, a political revolution was about restoring an established order rather than the creation of a new and different one.

Whilst we recognise that revolution as both a concept and activity, in whatever sphere it is examined, is a complicated one that defies simple and emphatic definitions, we also point out that the Glorious Revolution is a stark contrast to the current acceptance of what denotes a revolution. For example, Giddens (1989) suggests that a revolution has three key characteristics. First, a revolution must involve a mass movement, second, violence is a key component of revolution either by threat or by action and, finally, the revolution must lead a major process of change and reform. This final component of revolution may be relatively uncontroversial but the same does not necessarily apply to the first two elements. For example, Burleigh (2000) places more emphasis on small groups and "marginal sects" in the early stages of a revolution that provides the foundations of the mass movements of Giddens. Calvert (1967, 1970) approaches the concept of revolution from a different direction and proposes a framework for analysis which suggests that there are four key aspects of a revolution. The revolution has a process which defines the way in which the activity is carried out, the revolution has an event which signifies a starting point or moment of crisis, the revolution has a programme which defines the objectives and hoped for outcomes and, lastly, the revolution has a "political myth" which suggests that, whilst it may be an idea that forms an important part of the beliefs of different groups, it is not necessarily founded on fact.

Having established the complexity of the concept, we now turn to consider some of the key elements of the concept from the literature that offers a commentary on political revolutions. In doing this we would immediately point out that we are not creating a definitive list of revolutionary characteristics but are, instead, creating an illustrative list against which the management school can be compared. To do this we will examine four common descriptors of political revolutions. Political revolutions are rare and characterized by infrequency. They are, to a large extent, unpredictable and, hence, uncontrollable. Revolutions in both theory and practice are not always positive and welcome and, finally, revolutions tend to lead not to change but to counter-revolutionary reactions.

Despite the huge volume of literature on revolutions, we should not lose sight of the fact that they are not regular events. Burleigh draws attention to their rarity and argues that this rarity is explained by the conditions required for a revolution to occur. These conditions are the presence of a revolutionary messiah and the appearance of some sort of ontological crisis. The idea of revolutions requiring a certain set of conditions is echoed in elements of the Marxist view which draws attention to economic or class based crises and the Leninist view which draws attention to the importance of the revolutionary agent. Once the revolution has begun, a significant body of commentary suggests that it will act in an unpredictable and uncontrollable manner. For instance, Skocpol (1979) suggests that revolutionary activity develops its own momentum and 
behaves in a manner which may be beyond the influence of the revolutionary; "it is not the revolutionaries who make revolutions, revolutions are non-voluntary". This view further reinforces that of Giddens who drew attention to the violent nature of revolution and the unpredictability that often accompanies any violent act.

The rarity of revolutions is, therefore, explained by some as a consequence of the circumstances that must be in place before revolution can occur. Their rarity could also be explained by their fundamentally negative nature. For Skocpol this negativity begins at the start of the process as revolutions are built more on the weaknesses of an existing system than on any positive actions. More dramatically, Brinton (1952) draws similarities between revolutions and fevers and argues that, like any illness, the best response is to cure it rather than promote it. This is supported by Edwards (1970) who makes the further point that a possible positive outcome of revolution is that those affected by this type of fever may be become immunised from its effects. Therefore, future revolutions may be difficult to deliver. This raises the final point of counter-revolution and reaction which is certainly supported by experience. Here, we can draw attention to the outcomes of the Russian and French revolutions and use them to reinforce our earlier Glorious Revolution perspective. For example, the outcome of the Russian Revolution was not the communist utopia dreamt of by Marx but the emergence of the Red Czar, the five-year plans, one-party domination, mass murder and uniformity. Likewise, the French Revolution led to The Terror, the Emperor and the Napoleonic codes, which brought about greater order and uniformity than ever existed under the Bourbons.

The political perspective of revolutions is, therefore, complex and, at times, confusing. One key question that requires further investigation concerns the extent to which this political approach has translated well into a management approach. Is it time to discard our copies of Drucker, Moss Kanter and Mintzberg and replace them with Marx, Trotsky and Lenin? Skocpol has already questioned the appropriateness of much social scientific treatment of revolutions and argues that the "revolutionary process itself was envisaged in ways that correspond very poorly to the histories" and this was because explanations focused on "models of how political protest and change were ideally supposed to occur" rather than on what happened in reality. We can examine this point further by considering some of the key elements of the revolutionary school of management and we will begin with the terminological similarity between these two approaches in their treatment of change.

If, as De Wit and Meyer (1998) argue, strategy is about the realization of change, then it may not be surprising that the management revolutionaries make use of this political concept of revolution. This is because traditional theories of organizational and strategic change have, perhaps, become disconnected from practice and what is happening in the real world. These traditional theories usually focus on either extrapolation of the past to predict the future or emulation of the successful to deliver a competitive advantage. The revolutionary school of management generally argues that these are inappropriate approaches to strategy formation because the world is now a very different place and subject to ever more dramatic and turbulent changes. This is the first assumption on which this school rests; we live in revolutionary times. Following on from this is a second assumption which runs through much of the literature; organizations must become much more revolutionary in their strategy making, in particular, organizations should foster internal conditions of permanent 
revolution. The final assumption of the revolutionary school is that the main agents of revolution are managers who must think and act in a more creative and innovative way.

Before examining these assumptions in more detail it is important to place them into a broader context. A substantial proportion of the revolutionary school pays attention to two related change forces that organizations must contend with. First, the school has developed against a backdrop of globalization and, second, it has developed during a period of apparent rapid technological change. In considering the globalization context of management revolutions, we do not have the time or space in an article of this length to engage in the debate on the processes and forms of globalization and, instead, would simply offer some illustrations of the debate. Held and McGrew (2000) argue that "the phenomenon of globalization has captured the public imagination ... globalization has become the leitmotif of our age" yet despite the prominence of the issue there is little consensus about what it means, what is driving it and what the outcomes of it will be. The management revolution is taking place during a period of uncertainty "where the rules are in flux - and not clearly known" (Thurow, 1996).

With the odd exception (for example Hirst and Thompson, 1999) much of the literature on globalization starts with the a priori assumption that it is different and new. Moss Kanter (1996) talks about "sweeping changes in the competitive landscape", Prahalad and Doz (1986) discussed a world "beyond the analysis of existing rules" and Taniguchi (1995) explained a world that was "unpredicted and unpredictable, and it remains in flux". The consensus that things are changing is matched by a broad agreement that something has to be done about it. Ohmae (1989), for example, argues that, as globalization creates new challenges, then "we must globalize to meet them" and, in doing so, Moss Kanter argues that organizations need to "re-think their strategies and structures". Bartlett and Ghoshal (1987) offer an almost revolutionary prescription because this means "not only a total strategic reorientation but a major change in organizational capability as well". All of this is pretty uncontroversial strategic management in a global context: Organizations must change with their environments.

A more controversial debate is in what drives globalization and this raises the issue of technological change which is often used by the management revolutionaries. In our revolutionary school, technology matters for two reasons. First, it is a significant catalyst for revolutions and, second, it can be the means through which the revolution is managed and directed. One of the earliest examples from this revolutionary school (Levitt, 1983) argued that there was a force driving us towards "a new commercial reality ... and that force is technology" and Giddens (1999) argues that, in a globalizing world, we must have "a much more active or engaged relationship with technology than used to be the case". On a more populist note, Pritchett (1998) draws attention to the revolution in information technology and explains that "Computer power is now 8,000 times less expensive than it was 30 years ago. If we had similar progress in automotive technology, today you could buy a Lexus for about $\$ 2$. It would travel at the speed of sound and go about 600 miles on a thimble of gas".

Given the volume of literature available on management revolutions, in shifting the focus from context to specifics the difficult part is in knowing where to begin. A brief consideration of the Harvard Business Review suggests that an important theme of the 
management revolutionaries is dealing with the obstacles to organizational transformation. For example, Beer and Nohria (2000) suggest; "Today's fast paced economy demands that businesses change or die. But few companies manage corporate transformations as well as they would like". One possible explanation of this problem is given by Collins (1999) who argues that corporate executives fail in transformation because even "with the best of intentions, they install layers of stultifying bureaucracy". The need for a more revolutionary approach to transformation is given by Pascale et al. (1997) who point out the weaknesses of an incremental approach; "More and more companies struggle with growing competition by introducing improvements into every aspect of performance. But the treadmill keeps moving faster, the companies keep working harder, and results improve slowly or not at all". A more useful approach than a general description of the revolutionary arguments is a more specific explanation of some of the key texts of the revolutionary school to see how they draw on the influence of the political revolutionaries.

Two of the most important texts in the revolutionary school are Hammer and Champy's (1995) Reengineering the Corporation and Gary Hamel's (2000) Leading the Revolution and these will form the basis of our analysis. We have chosen these texts for four reasons. First, whilst they are a small sample, they are broadly indicative and representative of the revolutionary school of management. Second, both sets of authors are widely praised as experts in their field: Hamel, according to The Economist, is "the world's reigning strategy guru" and Hammer is the management guru of choice for Business Week. Third, just as the authors have a wide currency, so too do their books: Reengineering the Corporation has spent weeks on the New York Times bestseller list and the founders and CEOs of leading corporations have endorsed Leading the Revolution. Finally, both books share a similar structure and process of argument that involves establishing the need for revolution, explaining the processes of revolution and illustrating best practices in revolutions.

In establishing the need for revolution, Hammer and Champy argue "Advanced technologies, the disappearance of boundaries between national markets and the altered expectations of customers who now have more choices than ever before have combined to make the goals, methods and basic organizing principles sadly obsolete". This view of the world is echoed in Hamel's work when he argues that; "We stand on the threshold of a new age - the age of revolution ... change has changed. No longer is it additive ... Today we live in a world that is all punctuation and no equilibrium". For Hammer and Champy this is driven by changes to customer expectations, multidimensional and intensified international competition and constant, ever faster change. Hamel's interpretation of the world is driven by factors such as technological advance, the reduced cost of technology, globalization and bare-knuckle capitalism, the Internet, deregulation and privatization.

Having established the need for revolution, the next step in the argument is to establish how the revolutionary change or transformation should be carried out. Discussion of change within organizations is often driven by the difference between the continuous and discontinuous paradigms. According to Mintzberg et al. (1998) much of this debate is influenced by another non-management discipline, Biology, as it mirrors the debate between Gould's punctuated equilibrium and Darwin's theory of evolution. Our revolutionaries come down on the side of Gould. For Hammer and Champy change becomes the most dramatic of activities; "Reengineering can't be 
carried out in small and cautious steps" because it involves "tossing aside old systems and starting over". During the revolution, activity is governed by four key words: Fundamental, Radical, Dramatic and Process. To translate these words into real action the organization must have a process orientation, an ambition for breakthroughs, embrace rule breaking and make creative use of information technology. Hamel offers a similar prescription. He argues "To be an industry revolutionary, you must develop an instinctive capability to think about business models in their entirety ... this is mental training for industry revolutionaries". With the mindset comes the revolution: "How to start an insurrection ... Build a point of view ... Write a manifesto ... Create a coalition ... Pick your targets and pick your moments ... Co-opt and neutralize ... Find a translator ... Win small, win early, win often ... Isolate, infiltrate, integrate".

Rather than being a reflection, this may actually signify a contradiction of the political origins of the revolutionary concept. For Hamel and Hammer and Champy, the purpose of revolution is to create organizational instability as a direct counter to organizational stability; only under these kind of organizational conditions can a firm cope with the revolutionary times. However, in the political tradition of Hobbes, for example, the purpose was not to impose instability but rather to counter the revolution; the role of the Leviathan was to bring order to chaos and not vice versa. Within this context, Chaharbaghi and Newman (1996) argue that one of the central problems in maintaining a revolution lies in the population profile of the organization. Two key groups in the organization are the creators who begin the revolution and the stabilizers who manage the organization post-revolution. If the revolutionary process is to become permanent then management must always pay attention to the political power relationships between these groups. De Wit and Meyer expand on this point and draw attention to a major problem for the management revolutionaries; "Humans have a strong preference for stability". Under these conditions, small changes in the organization will never be enough and, instead, "a co-ordinated assault is usually required". This shock-therapy approach is endorsed by Hamel who views organizational success, not as a one-off revolutionary change, but as a permanent process within the organization. The key task is to revolutionize again and again; "Unless a company can institutionalize activism, its' unlikely to be able to meet the twin challenges of revolution; reinventing itself and reinventing its' industry".

The management revolution literature is, therefore, driven by a compelling logic. Times are revolutionary, this must be reflected in the management of the organization and the revolution must become permanent because further globalization and technological development will make the future even more dramatic than the already revolutionary present. This brings us full circle and back to the political revolutionaries like Trotsky (1930) who argued; "The completion of the revolution is unthinkable ... the revolution thereby becomes a permanent revolution". We can now turn to examine these points in more detail through an examination of two examples of recent "revolutionary" European change. The case study on the Delor's Plan and developments in the European Union examines the extent to which the European business environment has changed during a period of transformation and the Ford case study examines the background and process of the company's European Transformation Strategy and the extent to which it can revolutionize the organization. 


\title{
Case Study 1: The Delor's Plan for a European Revolution
}

\author{
"This large market that we are creating is of direct concern to every \\ citizen of Europe. It is revolutionary" Jacques Delors
}

In the UK, current discussion about the EU tends to focus on the single currency and whether or when Britain should join the eurozone. Much of the debate on this issue misses the important point that the single currency is only one step in a much longer process. The historical origins of this process began in 1957 with the signing of the Treaty of Rome that created the (now) European Union. Since 1957, the Union has developed in two reasonably distinct phases. The first phase, which lasted up until the mid-1980s, focused on widening the Union and saw the number of member states grow from 6 to 12 to 15 ; by 1986 the Union had a consumer market of over 300 million people. By the mid-1980s, however, this approach had reached its natural geographic, economic and political limits and so a new phase in development was needed. This second phase of development saw a shift in emphasis away from widening towards a deepening of the Union. At the center of this shift was Jacques Delors, the President of the European Commission, and the Delor's Plan for economic and monetary union (EMU).

The Delor's Plan proposed that deepening should happen in 3 stages. Stage 1 was launched by the Single European Act and was operationalised in the 1992 Programme. This stage focused on the completion of the internal market which was to be achieved through the removal of the final remaining non-tariff barriers to trade. Thus, the 1992 Programme promoted, amongst other things, the removal of customs points between member states, the harmonization of technical standards and the opening up of government procurement practices in an attempt to facilitate the free movement of goods and services within the Union. Having completed the single market, Stage 2 aimed to strengthen economic co-operation and co-ordination between member states in order to deliver convergence of economic performance in preparation for the launch of the single European currency. The final stage was the launch of the single currency itself for those member states that (a) fulfilled the economic criteria for joining and (b) wanted to join. With just a few exceptions, each stage of the Plan has been completed on time.

The rationale for the first stages of the Delor's Plan was primarily based on research evidence provided by the Cost of Non-Europe Survey (1988). Broadly speaking, the survey suggested that European business would always be held back from becoming globally competitive if the EU remained a fragmented collection of individual states (European Economy, 1988). Therefore, EMU was sold as a revolutionary step that should be taken because it would bring enormous benefits to European business and everyone living in the Union: Improvements to macro-economic conditions and performance would filter down to improvements to micro-economic conditions and performance. Whilst the survey was huge in its scope, it was popularized through the Cecchini Report (1988) that served as a sort of executive summary.

For Cecchini, Stage 1 of the Delor's Plan was crucial for two reasons. First, it would provide massive economic benefits. The Cost of Non-Europe Survey quantified the direct and indirect economic benefits of the 1992 Programme as between 4.3 and $6.4 \%$ of GDP. In financial terms, every European consumer would, at worst, be 
euro500 better off. The second reason why Cecchini supported Stage 1 was that, if completed successfully, it would provide momentum for the rest of the EMU project. Cecchini argued that "A dramatic new environment awaits consumers and producers alike in the integrated community market post 1992". On a similar note, for others 1992 could not have come at a better time. "There is a growing sense that Europe, and European companies, need, and want, a fresh momentum. A fresh destiny if you want a more romantic idiom ... after 1992 business in Europe might never be the same again" (SRI International, 1988).

Whilst the process of any revolution is always interesting, perhaps a more important focus for analysis should be the results of the revolution. Lord Cockfield, VicePresident of the Commission, argued that the revolutionary changes proposed in the Delor's Plan would deliver "significant inflation free growth and millions of new jobs". In judging the effects of the changes, it is, therefore, reasonable to use these criteria and in doing so we need to answer two key questions. First, did the changes deliver a significant improvement in European economic performance? Second, did the changes deliver a significant improvement in comparative economic performance? Over a century and a half after the event, Mau Tse Tung was asked about the effects of the French Revolution. His reply was that it was still too early to say. Even with this caveat in mind, the economic effects of the Delor's Plan would seem to have been disappointing.

Table 1 considers European economic performance across three distinct time periods. The first, 1984-1989, considers performance in the immediate period before the launch of the Delor's Plan and the 1992 Programme. The 1990-1995 series considers the immediate impact of the completion of the single market and the final time series, 1996-2001, examines more recent economic data following Stages 2 and 3.

Table 1: EU Economic Performance 1984-2001

\begin{tabular}{|l|l|l|l|}
\hline & $\begin{array}{l}\text { Average Growth in } \\
\text { GDP (\%) }\end{array}$ & $\begin{array}{l}\text { Average Inflation } \\
\text { Rate }(\%)\end{array}$ & $\begin{array}{l}\text { Average Unemployment } \\
\text { Rate }(\%)\end{array}$ \\
\hline $1984-1989$ & 3.0 & 4.9 & 9.7 \\
\hline $1990-1995$ & 1.8 & 4.2 & 9.5 \\
\hline $1996-2001$ & 2.5 & 2.1 & 9.3 \\
\hline
\end{tabular}

Source: OECD

There can never be any absolute certainty over the outcome of a revolution because, by their nature, they operate on the edge of chaos. The broad economic data in Table 1 offers a mix bag of outcomes and, therefore, raises a number of important issues. The main success story is in the significant reduction in inflation which has more than halved during this period. However, a logical question to ask is what this low inflationary environment has delivered, especially in terms of economic growth and job creation. Economic growth in Europe has been poor. Whilst much of the fall in economic growth in the early 1990 s can be accounted for by the slowdown in the global economy, European growth in the late 1990s was still significantly lower than it had been at the end of the previous decade. The natural corollary of low economic growth must necessarily be difficulties over job creation and, whilst European unemployment has fallen, the pace of the fall is neither significant nor dramatic. 
One of the main foundations of the Delor's Plan was that the environment in which it operated fundamentally influenced the performance of European business. Cecchini argued that one of the main effects of these conditions was that "European business steps out to confront global competition with lead weights round both feet". For European businesses to become global competitors, they would need similar environmental conditions to their main international rivals, particularly from the United States. Table 2 provides some comparative economic data on the EU and USA and shows that again the results of the revolution are, to date, disappointing as the American economy has proved much more adept at delivering low inflation, economic growth and new jobs.

Table 2: EU vs USA Economic Performance 1990-2001

\begin{tabular}{|l|l|l|l|l|l|l|}
\hline & \multicolumn{2}{l}{$\begin{array}{l}\text { Index of Real GDP } \\
\text { Growth 1990 }\end{array}$} & \multicolumn{2}{l|}{$\begin{array}{l}\text { Consumer } \\
\text { Index 1990 }=100\end{array}$} & \multicolumn{2}{l|}{$\begin{array}{l}\text { Price } \\
\text { Rate }(\%)\end{array}$} \\
\hline & EU & USA & EU & USA & EU & USA \\
\hline 1990 & 100.0 & 100.0 & 100.0 & 100.0 & 7.8 & 5.6 \\
\hline 1991 & 101.8 & 99.5 & 105.1 & 104.2 & 8.0 & 6.8 \\
\hline 1992 & 103.0 & 102.6 & 109.8 & 107.3 & 9.1 & 7.5 \\
\hline 1993 & 102.7 & 105.4 & 113.8 & 110.5 & 10.6 & 6.9 \\
\hline 1994 & 105.6 & 109.6 & 117.3 & 113.4 & 10.9 & 6.1 \\
\hline 1995 & 108.1 & 112.5 & 120.9 & 116.6 & 10.5 & 5.6 \\
\hline 1996 & 110.0 & 116.6 & 124.0 & 120.0 & 10.6 & 5.4 \\
\hline 1997 & 112.8 & 121.7 & 126.6 & 122.7 & 10.4 & 4.9 \\
\hline 1998 & 116.1 & 126.9 & 128.9 & 124.7 & 9.7 & 4.5 \\
\hline 1999 & 119.1 & 132.1 & 130.5 & 127.4 & 9.0 & 4.2 \\
\hline 2000 & 123.0 & 137.6 & 133.8 & 131.8 & 8.1 & 4.0 \\
\hline 2001 & 125.1 & 139.1 & 136.5 & 135.7 & 7.8 & 4.8 \\
\hline
\end{tabular}

Source: OECD

The broad economic evidence presented suggests that, to date, there has been no "prodigious and influential upheaval" (Hobsbawn, 1975) in the European business environment. Williams et al. (1989) argue that this is because it was always unlikely to happen given the revolutionary means proposed in the Delor's Plan. They argue that this was never really the in any case as it was not about revolution but rather momentum. As a result of the stalling of development of the Union by the mid-1980s through the limitations reached on widening, the union had become characterized by "low wrangling" and the Commission had "a reputation for pointless regulations". The hidden agenda behind the Delor's Plan was not dramatic change but rather an attempt to give the Union something constructive to do.

\section{Case Study 2: Continuous Revolution at Ford Europe: From Ford 2000 through the ETS to Back to Basics}

"Our exciting transformation continues to accelerate" Jac Nasser

This article now turns to the micro-level to examine revolutions in an organizational setting. Since the late $18^{\text {th }}$ and early $19^{\text {th }}$ century an almost universally accepted definition of the outcome and objectives of the capitalist firm is to deliver a financial surplus to its owners. This is the outcome that the internal processes, regardless of 
how they are constructed and managed, are aimed at delivering. When this outcome fails, the revolutionary school attempts, through processes such as BPR, to reinstate it. We would argue that this cannot constitute a revolution for three reasons. First, it simply does not cover the scope required of revolution. In defining and explaining the nature of political revolutions, Calvert proposed that revolutions are constituted by processes, events, programmes and myths and it is the combination of these four elements that define the revolution. If attention is paid only to the processes of revolution then significant parts of the revolutionary package are ignored. Second, the revolution is not about creating a new order but reinforcing and protecting the existing one; without changes to the definition of outcome, revolution cannot take place. Finally, if it is accepted that outcomes should stay the same, any changes to the internal processes are handicapped and limited as the organization will be stuck with the same old structural internal conditions, usually expressed in financial terms, that cannot be revolutionized. We can develop these points further through an examination of Ford Motor Company.

Over the past decade, Ford's strategy has operated at two levels. There has been a global strategy that acts as the main driving force for the whole organization and, more recently, there has been a distinct, but not completely separate, strategy for the European operations. Whilst this article is concerned with Europe, it is nevertheless important to place Ford's European strategy in a global context. The global strategy, Ford 2000, was launched in the early 1990s by then Chief Executive Alex Trotman. Updated with the Spirit of Ford initiative in 1999, the strategy has the clear and precise objective that Ford should become "the world's leading consumer company for automotive products". Central to Ford 2000 was the creation of a global management structure that would, in particular, more closely integrate the North American and European operations. This strategy has been operationalised in a number of ways including the creation of the Premier Automotive Group through the purchase of brands like Jaguar, Land Rover and Volvo and related diversification through the acquisition of companies like Hertz and Kwik Fit.

The key test of a strategy is not in what is written down but rather what is executed. For example, Moss Kanter argues that one common problem with global strategies is that they may become divorced from what is happening at the local level. Ford 2000 was supposed to create a global car company with five main characteristics: A strong global brand through the blue oval, improved levels of customer satisfaction and loyalty, the provider of best value to customers, a flexible and leadership driven organization and a benchmark for corporate citizenship. However, by the late 1990s it was clear that these were not characteristics to be found in Ford Europe. Simply put, for the past 10 years Ford has been in retreat in Europe. The company's market share has been falling constantly since the start of the 1990s. For example, in 1991 Ford was the third biggest player in the European industry but by the end of the decade its relative position had fallen to fifth. Despite steady, if unspectacular, growth in the car market overall, Ford was selling 10\% fewer cars at the end of the 1990s than at the beginning.

Whilst being fragmented, the European car market is dominated by the five biggest national economies (Germany, France, Italy, Spain and the UK) as, between them, these markets account for more than of $80 \%$ of all cars sold in the Union. In these crucial markets, Ford has been losing significant market share. Over the past 10 years, 
Ford's share has fallen from 15 to $12 \%$. Loss of market share in these markets is always going to be critical for Ford because the company has been unable to find significant growth in the smaller but faster growing national markets of the EU. The result of this is that, over the past decade, market share in the Union as a whole has fallen from 14 to $11 \%$. Table 3 presents some market share data to illustrate these points.

Table 3: Ford's Market Share in the EU Passenger Car Market (\%)

\begin{tabular}{|l|l|l|l|l|l|l|l|}
\hline & EU15 & Germany & France & Italy & Spain & UK & Big 5 \\
\hline 1991 & 14 & 12 & 9 & 13 & 14 & 30 & 15 \\
\hline 1992 & 13 & 10 & 9 & 11 & 17 & 26 & 13 \\
\hline 1993 & 14 & 11 & 9 & 10 & 16 & 26 & 14 \\
\hline 1994 & 14 & 12 & 9 & 11 & 18 & 27 & 15 \\
\hline 1995 & 15 & 12 & 9 & 11 & 19 & 26 & 15 \\
\hline 1996 & 14 & 12 & 9 & 10 & 17 & 25 & 14 \\
\hline 1997 & 14 & 13 & 9 & 10 & 15 & 21 & 14 \\
\hline 1998 & 13 & 12 & 9 & 9 & 13 & 22 & 13 \\
\hline 1999 & 12 & 9 & 8 & 9 & 13 & 24 & 12 \\
\hline 2000 & 11 & 9 & 7 & 9 & 13 & 21 & 12 \\
\hline
\end{tabular}

Source: SMMT, ACEA

The most dramatic collapse in market share has occurred in the UK. Historically, this has been Ford's most important national market and performance in the UK is broadly indicative of Ford's overall European retreat. Within the UK, more than $80 \%$ of Ford's sales have come from 3 segments: The B segment filled by the Fiesta, the C segment filled by the Escort and, more recently, the Focus and the C/D segment where the Mondeo was introduced to replace the Sierra. Ford has not been able to find a must-have product in any of these segments and the result of this is further erosions in market position. For example, the Fiesta's market share more than halved during the last decade and, in the same period, $\mathrm{C}$ segment market share fell by $12 \%$. The situation has been less critical in the C/D segment where market share has fallen by just $2 \%$. The only real success stories enjoyed by Ford over the past 10 years have been in the small niche markets for cars like the Ka, Cougar and Galaxy but the size of these segments mean that they can never sell in sufficient volume to offset reductions elsewhere.

We have argued elsewhere (Williams et al. 1995) that, in the cars business, market performance is the crucial determinant of a company's success or failure. Given Ford's market performance, poor productive and financial performance is a logical and necessary outcome. Despite a significant restructuring programme over the past few years which has involved the closure of plants in, for example, Portugal, Poland and Belarus and significant rationalization of plants in the UK, Ford still has a number of productive challenges to overcome. For example, declining sales in the market have left Ford with excess capacity estimated at $29 \%$ of total capacity compared to a $15 \%$ average across other European manufacturers (Ford Company News). An irrefutable equation of management is that declining market share plus low capacity utilization must always equal disastrous financial performance. In only 3 years in the 1990s did the company generate a financial surplus and, over the decade, accumulated losses amounted to almost $\$ 3.5$ billion. 
Ford's explanation as to why things have gone wrong is based on four factors. There have been insufficient improvements to quality, the launch of new products has been poor, there have been blockages in the pipeline of new products and cost reduction has not happened at the pace that it should have done (Ford Company News). As a direct response to the long-term decline in performance and the perceived causes of that decline, in mid-2000 Ford launched the European Transformation Strategy (ETS). In common with the Ford 2000 global strategy, central to the ETS is transformation through market leadership. However, if Ford 2000 was driven by lofty ambitions, the ETS is more of a strategic response to a failing market position and subsequent financial crisis. As well as the restoration of financial health, a key objective of the ETS is to become different rather than simply better and this difference should deliver "quantum improvements" (Ford Company News). In keeping with the company's history, the strategy follows Henry Ford's maxim that "hard work alone does not accomplish much" and so emphasis is placed on innovation, flexibility and diversity.

In the late 1970s and early 1980s the strategic response of British Leyland to a similar, albeit more spectacular, decline in market performance was Michael Edwardes "product led recovery" (Williams et al., 1986). Twenty years later the centerpiece of the ETS is that recovery will be delivered in the marketplace because "transformation will be driven by a flow of exciting new products" (Ford Company News). The ETS is to operate in three dimensions: a product dimension with the launch of 45 new products in a five year time scale; a distribution dimension aimed at making improvements to Ford's system and processes of delivery to customers and a cost reduction dimension which will make a major contribution to the restoration of profitability. Operationalisation of the strategy will occur in a number of ways which includes new product strategies, intensification of the use of assets, improving relationships with customers, enhancing the brand and speeding up the process of order to delivery.

The extent to which the ETS can deliver the intended transformation may well depend on three factors. First, if the transformation is to be product led, then the market conditions in Europe will have a major influence on the outcome of the strategy. The second factor is the extent to which the ETS is different and revolutionary compared to previous forms of strategy in this business. The final factor is the ability and willingness of the company to think in a revolutionary way in order to overcome any internal obstacles to transformation and revolution. We can briefly consider each of these factors in turn.

The European car market is structurally weak because not only is it approaching saturation but also competition is intensifying. Growth in the park of cars in use in Europe to almost 180 million by 2000 raises questions about any future growth in the market. With over 1 car on the road for every economically active European, the future pattern of growth is likely to be both unsteady and slow. Over the past decade the market has followed a pattern of sharp falls on the economic downswing followed by a slow recovery on the economic upswing. Over the 1990s the market grew by just $10 \%$. Table 4 summarises some of the evidence on this issue. 
Table 4: European Car Market Demand and Saturation

\begin{tabular}{|l|l|l|l|l|}
\hline & $\begin{array}{l}\text { EU15 New Car } \\
\text { Registrations } \\
(\mathrm{mil})\end{array}$ & $\begin{array}{l}\text { Index of New Car } \\
\text { Registrations } \\
(1990=100)\end{array}$ & $\begin{array}{l}\text { EU15 Park of } \\
\text { Cars (mil) }\end{array}$ & $\begin{array}{l}\text { Cars per } \\
\text { Economically } \\
\text { Active }\end{array}$ \\
\hline 1990 & 13.124 & 100 & & \\
\hline 1991 & 13.048 & 99 & 146.1 & 0.94 \\
\hline 1992 & 13.149 & 100 & 150.3 & 0.96 \\
\hline 1993 & 10.932 & 83 & 154.9 & 0.99 \\
\hline 1994 & 11.584 & 88 & 157.9 & 1.01 \\
\hline 1995 & 11.669 & 89 & 161.0 & 1.03 \\
\hline 1996 & 12.398 & 94 & 164.1 & 1.04 \\
\hline 1997 & 13.005 & 99 & 167.7 & 1.07 \\
\hline 1998 & 13.941 & 106 & 171.4 & 1.09 \\
\hline 1999 & 14.632 & 111 & 175.2 & 1.11 \\
\hline 2000 & 14.308 & 109 & 178.1 & 1.13 \\
\hline
\end{tabular}

Source: ACEA

Intensifying competition worsens problems of market saturation in Europe. For example, the last five years have seen a resurgence in the fortunes of VW and General Motors (mainly at the expense of Ford) and further fragmentation of the market. Between 1990 and 2000, the number of manufacturers in the B segment increased from 13 to 15 and the number of competing models from 13 to 21 . The situation in the C segment, historically Ford's most important, is more dramatic with the number of suppliers increasing from 21 to 24 and the number of models from 36 to 49 .

The ETS raises some interesting issues surrounding the difference between strategies of innovation (where the objective is to deliver difference) and optimization (where the objective is to deliver improvement). With slow growth and intensifying competition in the market, the extent to which transformation will occur could depend on how innovative the strategy is. The ETS focuses directly on the root causes of poor performance and offers a blend of cost recovery and cost reduction strategies such as new launch plans, increased attention to fixed costs, more integration between order, delivery and the distribution network and increased commonality amongst platforms and components. Can a new dish be created with old ingredients? As a post-script to the ETS, given that Ford's North American operations now face similar difficulties to the European side of the business, the company has embarked on a global strategy of transformation. This global transformation will come about in four different ways. First, The ETS will continue. Second, North America will develop a distinctive transformation strategy of its own. Third, the non-core businesses will be refocused and, finally, the Premier Automotive Group will be expanded. The strategic motto chosen by Ford for this global, forward-looking, transformation strategy is "Back to Basics" (Ford Motor Company Website).

\section{Conclusions and Implications}

"A tale ... full of sound and fury, signifying nothing" Shakespeare

The aim of this article was to analyse the revolutionary school of management and draw attention to the political origins of much of the language that it utilizes. As a substantial part of the discussion has centred on the appropriation of language from an 
outside discourse, a fair question would be about the extent to which this article represents nothing more than academic pedantry about the use of words. Our answer to this question would be both yes and no. We answer yes because we agree with Porter and Teich's point about the inflation of vocabulary leading to a cheapening of the term "revolution". Similarly, the management revolutionaries ignore Levi's warning about the difference between the naming and the meaning of phenomena.

We would note that there is a similarity between the terminology of the management and political revolutionaries that may reflect some superficial similarity in intent. Lenin (1982) argued, "revolutions are the locomotives of history. Drive them full speed ahead" and this may well have influenced Hammer's (1996) view that "organizations can accommodate the forces of change only by creating and institutionalizing a capacity for changing themselves". On a similar note, Hamel focuses on creativity as a key means of revolution; "Unless you and your company become adept at business concept innovation, more imaginative minds will capture tomorrow's wealth" which echoes the Trotsky view that "revolution is an expression of the impossibility of reconstructing by rational means. Insurrection is an art".

Whilst we may argue that these similarities in language are somewhat superficial, it should not detract from a basic point that the use of language is very important. For example, Sillence (1999) examines the relationship between organizational change and language. He argues that, in both the management of the change process and in any post-rational analysis of the change process, language has a crucial role to play. As an illustration of this, the Theory of Political Language Forms can be used to explain some of the important effects of the type of language used. Using this framework, Sillence argues that language can be instrumental to change as it can enhance commitment and motivation, build cohesion and provide a wider view of an organization's interests and direction. Alternatively, Speech Act theorists argue that what is said matters, not just because of the form of words used, but also because of the intention behind the words used: In making judgments, measurement should be made of the results of language as well as the words.

The idea of measuring the intention behind the use of language brings us nicely onto the implications for management of these issues. Perhaps a first lesson from the cases is to avoid making promises that cannot be kept. The European Union has always struggled with the issue of momentum and of having something important to do. Without a big project, disillusionment with the Union is always likely to set in given the propensity of the Commission to engage in bureaucratic interference in issues of great personal aggravation but limited importance. Whilst the Delor's Plan provided something substantial and constructive for the Commission to oversee, it was always going to be difficult to see how revolutionary fervor was going to be whipped up by relatively bland and technical measures like the harmonization of technical standards across member states for the fitting of backseat seatbelts. What was supposed to be revolutionary was not so much the process as the outcome. However, disillusionment with the Union is unlikely to be overcome when the dramatic new environments promised run counter to the everyday experiences of European citizens and businesses.

In developing this theme further, the Ford case study also raises difficult issues about the limitations of revolution and transformation. Kuhn (1996) argued that science is 
not the steady cumulative acquisition of knowledge. Instead, science is "a series of peaceful interludes punctuated by intellectually violent revolutions" where "one conceptual world view is replaced by another" In science, therefore, revolutions are characterized by paradigm shifts. However, the management revolutionaries, in both theory and practice, fail to propose the means or theoretical basis for a Kuhnian paradigm shift because the underlying fundamentals are, despite the emotive rhetoric, never challenged. For example, with the ETS the objective of generating a financial surplus for the purposes of shareholder value remains the same and all that is proposed is normal management wrapped up in a rhetorical and ideological spin. A key assumption of the revolutionary school is that of the manager as revolutionary and agent of change. We have argued elsewhere (see Williams et al., 1994 and 1995, Adcroft and Willis, 2000) that in the cars business the most important determinant of success and failure is not the role played by management but rather the external market conditions faced. Market conditions of saturation, slow growth and intensifying competition severely limit the ability of firms to either reduce costs internally or improve cost recovery from the market. Therefore, when structural conditions in the market turn against the firm, transformation is difficult if not impossible and this is especially so when the vehicle of transformation is a reworking of traditional cost reduction and cost recovery strategies.

Brinton argues that revolutions can be useful if they "destroy wicked people and useless institutions" which raises a certain irony about the revolutionary school of management. If only the strong can survive the fever of revolutionary change, why is it mainly the weak who latch onto the revolutionary guru's exhortations and try to implement them? Gramsci (1971) suggests that the successful prosecution of a revolution requires two equally import and mutually supportive processes; the war of position and the war of manoevre. The war of position is about knocking down the foundations and earthworks of the existing system and is an essential precursor to the war of manoeuvre, which is more traditionally associated with revolutionary activity. In our management context, the lesson is that unless the war of position is won, the war of manoeuvre will always fail. We would argue that organizations like Ford have gone for a war of manoeuvre precisely because they are losing the war of position.

More than anything else all this may illustrate that there is only a tenuous link between management research and the world of the practitioner. In considering some of the implications for management research, a case can be made against the inappropriate appropriation of theories and models from other discourses that soon become little more than clichés. As Hammer and Champy point out "reengineering has become part of the common parlance in the business press, on radio and television news and talk shows, in conversation; it has even become a sales pitch for some products and services. Unfortunately, many people who use the word don't understand it. Consequently a lot of half-right ideas and some plain nonsense are being passed off these days as reengineering". There is a certain irony in this. Just as Hammer and Champy are sent into a spin by the inappropriate appropriation of their ideas, perhaps the real revolution fostered by their work could be found in Marx, Trotsky and Lenin turning in their graves. 


\section{Bibliography}

Adcroft, A. and Willis, R. (2000) Innovation or Optimisation: Facing up to the challenge of the global economy in Barry, J., Chandler, J., Clark, H., Johnston, R. and Needle, D. (eds) Organisation and Management: A critical text, International Thomson Business Press, Reading, UK.

Arendt, H. (1963) On Revolution, Faber and Faber, London, UK.

Bartlett, C. and Ghoshal, S. (Fall 1987) Managing Across Borders: New organizational responses in Sloan Management Review.

Beer, M. and Nohria, N. (May 2000) Cracking the Code of Change in Harvard Business Review.

Brinton, C. (1952) The Anatomy of Revolution, Vintage Books, New York, USA

Burleigh, M. (2000) The Third Reich: A New History, Pan Books, London.

Calvert, P. (February 1967) Revolution: The politics of violence in Political Studies, Volume 15, Number 1.

Calvert, P. (1970) A Study of Revolution, Clarendon Press, Oxford, UK.

Cecchini, P. with Catintat, M. and Jacquemin, A. (English version by Robinson, J.) (1988) The European Challenge: 1992 The Benefits of a Single Market, Wildwood House, Aldershot, UK.

Chaharbaghi, K. and Newman, V. (June 1996) Innovating: Towards an Integrated Learning Model in Management Decision, Volume 34, Number 4.

Chaharbaghi, K. and Newman, V. (1997) The crisis of wealth creation in Management Decision, Volume 35, Number 7.

Chaharbaghi, K. and Willis, R. (1998) Strategy: The missing link between continuous revolution and constant evolution in International Journal of Operations and Production Management, Volume 18, Number 9/10.

Collins, J. (July 1999) Turning Goals into Results in Harvard Business Review.

Commission of the European Communities (1988) Research on the Cost of Non-Europe: Basic Findings, Volume 3, Luxembourg: Office of Official Publications of the European Communities.

De Wit, B. and Meyer, R. (1998) Strategy: Process, Content, Context. An international perspective, Thomson Learning, London, UK.

Edwards, L. P. (1970) Revolution and the Transformation of Societies, The Free Press, New York, USA.

European Economy (March 1988) Dimensions and Structure of the Internal Market

Ford Company News (various editions)

Fromm, E. (1960) The Fear of Freedom, Routledge and Kagan Paul, London, UK.

Giddens, A. (1989) Sociology, Polity Press, Oxford, UK

Giddens, A. (1999) Runaway World. How globalization is changing our lives, Profile Books, London, UK.

Gramsci, A. (1971) Selections from the Prison Notebooks, Lawrence and Wishart, London. UK.

Hamel, G. (2000) Leading the Revolution, Harvard Business School Press, Cambridge, USA.

Hammer, M. and Champy, J. (1993) Re-engineering the Corporation: A manifesto for business revolution, Harper Business, New York, USA.

Hammer, M. (1996) Beyond Reengineering: How the process centred organization is changing our work and our lives, Harper Collins Business, London, UK.

Held, D. and McGrew, A. (eds) (2000) The Globalization Transformations Reader, Polity Press, Cambridge, UK. 
Hirst, P. and Thompson, G. (1999) Globalization in Question, Polity Press, Cambridge, UK.

Hobsbawn, E. (1975) Revolution, XIV International Congress of Historical Sciences, San Francisco, USA.

Kuhn, T.S. (1996) The Structure of Scientific Revolutions, University of Chicago Press, Chicago, USA.

Lenin, V. I. (1982) Revolution and Power (Translated by Valence Ionescu), Longman, London

Levi, P. (1989) Other People's Trades, Michael Joseph, London, UK.

Levitt, T. (May 1983) The Globalisation of Markets in Harvard Business Review

Meier, C. (1996) Caesar, Harper Collins, New York, USA.

Mintzberg, H., Ahlstrand, B. and Lampel, J. (1998) Strategy Safari, The Free Press, New York, USA.

Moss Kanter, R. (September 1995) Thriving Locally in the Global Economy in Harvard Business Review.

Ohmae, K. (May 1989) Managing in a Borderless World in Harvard Business Review.

Pascale, R., Milleman, M. and Gioja, L. (November 1997) Changing the Way We Change in Harvard Business Review

Peters, T. and Waterman, R. (1982) In Search of Excellence: Lessons from America's best run companies, Nicholas Brierley Publishing, London, UK.

Porter, R. and Teich, M. (eds) (1993) Revolution in History, Cambridge University Press. UK.

Prahalad, C.K. and Doz, Y. (1986) The Multinational Mission: Balancing Local Demands and Global Vision, The Free Press, New York, USA.

Pritchett, P. (1997) New Work Habits for a Radically Changing World, Pritchett and Associates, New York, USA.

Scocpol, T. (1979) States and Social Revolutions: A comparative analysis of France, Russia and China, Cambridge University Press, Cambridge, UK.

Sillince, A. A. (1999) The role of political language forms and language coherence in the organizational change process in Organisational Studies, Volume 20, Issue 3.

SRI International (1988) On the Single European Act 1992, SRI International, Croydon, UK.

Taniguchi, M. (1995) Linkages: OECD and Major Developing Economies, OECD.

Thurow, L. (1996) The Future of Capitalism, Nicholas Brierly Publishing, New York, USA.

Usunier, J. (1998) International and Cross Cultural Management Research, Sage Publications, London, UK.

Williams, K., Williams, J., Haslam, C.(1986) The Breakdown of Austin Rover, Gower, Aldershot, UK

Williams, K., Williams, J., Haslam, C., Cutler, T. (1989) 1992:The Struggle for Europe, Berg Publishers Ltd, London, UK.

Williams, K., Haslam, C., Williams, J., Johal, S. with Adcroft, A. (1994) Cars: Analysis, History, Cases, Berghahn Books, Oxford, UK.

Williams, K., Haslam, C., Johal, S., Williams, J., Adcroft, A. and Willis, R. (February 1995) Management Practice or Structural Factors: The case of America verses Japan in the car industry in Economic and Industrial Democracy, Volume 16, Number 1. 
Williams, K., Haslam, C., Williams, J., Johal, S., Adcroft, A. and Willis, R. (1995) The Crisis of Cost Recovery and the Waste of the Industrialised Nations in Competition and Change: The Journal of Global Political Economy, Volume 1.

Womack, J., Jones, D, and Roos, D. (1990) The Machine that Changed the World, Rawson Associates, New York, USA.

Websites:

www.acea.be

www.ford.com

WwW.oecd.org

WwW.smmt.co.uk 